Kovács Norbert:

\title{
Horváth Gizella: Maine de Biran. Egy filozófus életútja*
}

Horváth Gizella monográfiája Maine de Biran gondolkodását és életútját mutatja be a magyar olvasóközönségnek. A kora 19. századi francia gondolkodó munkássága nemcsak magyar földön, hanem hazájában is kevéssé ismert, jelentőségét csak jóval halála után ismerte fel a filozófiatörténet. Munkásságának felfedezése után, mint a francia metafizika 19. századi megújítóját, a Descartes és Malebranche utáni legnagyobb francia metafizikust tisztelte benne Bergson, a kortárs filozófiatörténészek pedig a fenomenológia előfutárát látják benne. A kötet szerzője korábban művészetelmélettel és esztétikával foglalkozott, valamint érveléselméleti munkák szerzője. Horváth Gizella a Partiumi Keresztény Egyetem filozófia tanszékének vezetóje, 1994-es a francia reflexív filozófiáról írott doktori disszertációjában már foglakozott Maine de Birannal, ez a monográfia ennek a munkának a folytatása. Legújabb kötete életútjának ismertetése, filozófiájának eszmetörténeti elhelyezésén túl arra tesz kísérletet, hogy bizonyítsa, Maine de Biran filozófiája már a foucault-i értelemben vett modern episztéméhez tartozik.

Maine de Biran relatív ismeretlenségének oka részben az, hogy életében nagyon keveset publikált, másrészt teljes életmúve csak jóval halála után látott napvilágot 1959-ben.

Ugyanakkor nem igaz, hogy nem volt semmiféle hatással. Horváth szerint a francia filozófiát Maine de Biran rázta fel 19. századi szendergéséből. Az önreflexiót, mint módszert ő keltette újra életre a francia filozófiában; a pozitivista gondolkodás 19. századi uralma után Bergson spiritualizmusa markánsan magán viseli Maine de Biran hatását. Az élő test, mint filozófiai téma, az én elválaszthatatlansága a testtôl, szintén korán túlmutató és a filozófia történetben csak később, fenomenológiai kontextusban felbukkanó

\footnotetext{
* Pro Philosophia Kiadó, Múhely 13, 2005, Kolzsvár. 206 p.
} 
gondolatok. A fenomenológiával való egybevetésre azonban leginkább a közvetlen, átélt belső tapasztalatra építő én-metafizikája kínál lehetőséget Horváth számára. Egyes filozófiatörténészek pedig az empirizmus és a racionalizmus közti dichotómia meghaladási kísérleteként értékelték Maine de Biran filozófiáját. Horváth emellett kiemeli, hogy politikai gondolkodóként is eredeti meglátásai vannak, konzervatizmusa sajátos összhangban áll metafizikájával.

A könyv első fejezetében a szerző összefoglalja a filozófiai és történeti kontextust, megismerhetjük Franciaország 18-19. század fordulójának filozófiai életét, a korszakban ható irányzatokat. A 18. századi francia filozófia érdeklődése elfordult a metafizikától, témája Horváth kifejezésével élve az ún. külső ember, tendenciájában a 19. század végéig a pozitivizmus és az empirizmus illetve annak franciaországi adaptációja dominált. Condillac nyomán Locke empirizmusának továbbvitele révén alakult ki a francia szenzualizmus, amelynek központi tétele szerint az emberi lelki múködés levezethető az érzetadatokból. A francia forradalmat megelőző években a francia filozófia elvetette tehát a lélek „hipotézisét”. Maine de Biran, a nemesi származású egykori királyi testőr royalista adminisztrátor számára a francia forradalom korában az egyetlen releváns életcél a túlélés volt, a szabadság körének kialakítása, a belső függetlenség megtartása a külvilág hatásaival szemben. Így lesz Maine de Biran filozófiai programja az ember aktív természetének felmutatása, a szenzualizmussal és fiziológiai szemlélet ellenében egy önreflexióra alapuló metafizika kidolgozása. Ha lélek passzív és kizárólag egy érzet-köteg, akkor megkérdőjeleződik a belső függetlenség, nincs moralitás. A szenzualizmussal tehát a La Mettrie-féle ember-gép felfogás látszott visszatérni. Maine de Biran így elutasítja a kizárólag a külső tapasztalásra és az érzetekre történő hivatkozást. A tudat függetlenségét az „én”, mint biztos pont megerősítése szavatolhatja, ennek lehetőségét a reflexió képessége adja meg. Az én Maine de Biran számára nem evidensen adott, az erőfeszítésben nem megmutatkozik, hanem konstituálódik. Az én tehát egy közvetlen tapasztalati tény, nem elvont szubjektum. Az erőfeszítésben az én aktív - akaratereje nyilvánul meg a külsővel szemben. Az énkonstitució 
ugyanakkor a testtől elválaszthatatlan kölcsönhatásban valósul meg. Eljárása különbözik Descartes-étól, Maine de Biran szerint a gondolkodó szubsztancia fogalma nem vezethetô le a reflexióban adódó átélt tapasztalatból. Descarteskritikája nemcsak Kantéhoz hasonló, hanem Husserl megjegyzéseivel is hasonlóságot mutat. ${ }^{1}$

1803 és 1813 között gondolkodása pszichológiai szempontú, a tudat tényét, lehetőségének kérdését járja körül ebben a korszakban. A tudat vizsgálata során Maine de Biran a személyes szférához, az „én”-hez tartozó, illetve a külvilágból érkező ingerek elkülönítésére törekedett. A pszichikum szerinte nem redukálható a természeti jelenségekre, és bár tapasztalaton alapul az én, de ez csak belső tapasztalat, az eredendő tudati tény nem bizonyítható. Ezen a ponton veti egybe Horváth a fenomenológiai beállítódást Maine de Biran reflexió fogalmával. A szerző úgy véli, hogy Maine de Biran modernségének egyik oldalát protofenomenalizmusa jelenti. ${ }^{2}$

Érdeklődése a fenomenális, észleleti világtól 1813-tól kezdve fokozatosan a noumenális világ felé fordul, magyarázatra szorul ugyanis a reprezentáció maga, valamint - a szubjektum állandóság érzete, melyet az én tapasztalata nem biztosít, sőt az énre irányuló konstituáló erőfeszítésnek is származnia kell valamiből. Kénytelen tehát legalábbis hittel illetni a lélek szubsztanciájának tanát, és a realitások világát. A jelenségek szintje a realitások szintjére épül. Az abszolút létezők, a noumenonok csak fenomenálisan érhetőek el, egyébként csak hitünk lehet róluk. A „hivések” világában (melyet az ismerettel állít szembe) az én már nem lehet aktív, kezdeményező, a hivések világa az ember passzív oldalához csatlakozik. A hivések világa és az akarat viszonya problematikus. Így jut el Maine de Biran 1818-ra a vallásos fordulatig. A vallásossághoz részben az ontológiai „elköteleződéshez” vezet - az abszolút szubsztanciákhoz való eljutás utat nyit előtte a transzcendencia felé. Ugyanakkor egy új szemponttal gazdagodik vizsgálódása a francia történelem újabb és újabb fordulatai hatására: az ember, mint társadalmi létező

\footnotetext{
${ }^{1}$ Horváth 65.

${ }^{2}$ Horváth 88.
} 
problematikájával. A moralitás problémája önmagában is felerősödött: a rációt már erőtlennek találja magában ahhoz, hogy az akaratnak indítékokat és elveket adjon. A moralitásnak máshonnan, kívülről, felülről kell jönnie. Mivel az én már nem nyújt elegendő támaszt, nem elég erős az érzékiség visszaszorítására ezért a vallási megalapozású etika lehetősége felé fordul. Az akarat nem mindenható, nem áll hatalmában a boldogság elérése. A boldogság, mint az akaratra támaszkodó önuralom az emberi természettel látszik ellentétesnek számára. Maine de Biran a biztos pont keresése során a megváltásig, mint a külsődlegesig, mint kegyelemig jut el. A kegyelemben azonban, elveszik az erőfeszítés és elveszik az én és vele együtt az akarat és a szabadság is. Tulajdonképpen az én-feladásig, az Istenben való megsemmisülésig jut el gondolkodásában. A spirituális élet azonban Horváth szerint nem jelenti az énmetafizika visszavonását, a hit alapját ugyanis egy belső tapasztalat jelenti, ez pedig, az én területe. ${ }^{3}$

Politikai gondolkodása csak a munkanaplójából ismert. Horváth úgy véli, a politikát az antropológiai séma szerint építette fel Maine de Biran. Az ember létben ugyanis három „életet” ismer fel: az animális létre épül a sajátosan emberi lét, de a spirituális pedig egyfajta csoda. Az animális lét politikai megfelelője a demokrácia, az emberi lété az alkotmányos monarchia, a spirituális életnek pedig egyfajta spirituális megújulás, restauráció felelne meg. ${ }^{4}$ A politikának a jó társadalmat kell megvalósítania, alapja tehát csak az erkölcs lehet. Az erkölcs területén pedig az eredendő tapasztalat a kiindulópont. A reflexivitás társadalmi szinten is lehetséges, a szimpátiára való hajlam biztosítja az emberek közötti reflexív viszonyt. A hajlam és az erőfeszítés révén expanzív lelkierő fejleszthető ki, ennek segítségével lehetséges az individuális érzelmek kivetítése - az érzelmek tárgya így az emberi nem lesz, ez adja az etika és az egyetértés lehetőségét Maine de Biran társadalomfilozófiájában.

Horváth kiemeli a francia gondolkodó eredetiségét a jogról való gondolkodásban. Az emberi jogok felvilágosodás korabeli vívmányában Maine

\footnotetext{
${ }^{3}$ Horváth 154.

${ }^{4}$ Horváth 165.
} 
de Biran a partikuláris érdek mentén cselekvő ember fogalmát látja. A jog gondolkodásában elválaszthatatlan a kötelességtôl, hasonlóképp, mint a politika a moralitástól. Az expanzív lelkierő segítségével transzformálhatók a jogok kötelességekké, mivel a jogok, amik az egyént megilletik, a másikban is fellelhetőek kivetítve. A francia gondolkodó a hagyományos, konzervatív családanalógiára építő hatalom koncepciót az Istenhez való fiúi viszonnyal teljesíti ki - ezzel alkotva hivatkozási alapot a közösség számára, és teljesítve ki egy hierarchikus, tekintélyelvű társadalom elképzelését. Így részesedik a társadalom az isteni életből is. A monográfia egyik legérdekesebb gondolata éppen a három élet-koncepció és az elutasított forradalom hármas jelszavának összevetése: az állati élet az egyenlőség megfelelője, az emberi élet lényege a szabadság, az isteni összetevőben pedig, a testvériség megfelelőjét véli megtalálni Horváth. ${ }^{5}$ Maine de Biran politikai ideálja a legitim, erős, tekintélyelvú királyi hatalom volt. A forradalom, a liberalizmus, az emberi jogok fogalma, az egyenlőség pusztán a megtörtént, elszenvedett forradalom immár visszafordíthatatlan negatív következménye.

$\mathrm{Az}$ egyenlőség mennyiségi értelmezése az egyéniség eltűnéséhez, a népszuverenitás pedig az egyén szuverenitásának eltúnéséhez vezethet. Az egyenlőség tébolyában az emberek elveszítik önmagukat, a jólét és az érdekérvényesítés válik fontossá a közösség vagy a belső morális-intellektuális értékek helyett. Ez lehetne az antidemokratikus Maine de Biran politikai üzenete korunk számára - vonja le konklúziót Horváth Gizella.

Horváth Gizella könyve rendkívül olvasmányos, olvasóbarát filozófiai monográfia, mely miközben közelebb hozza a francia filozófia 19. századi dilemmáit, sikeresen mutatja be egy örökké úton levő magányos gondolkodó tépelődéseit és korának problémáira adott előremutató válaszait. A kötet legfigyelemreméltóbb megállapítása, hogy Maine de Biran gondolkodásában megy végbe elsőként és a legszembetűnőbben a történeti episztémé megváltozása. Ez a gondolat központi jelentőségú az elemzés során. Horváth rámutat, hogy Foucault maga sem figyelt fel erre, jóllehet az ún. ideológiai

\footnotetext{
${ }^{5}$ Horváth 181.
} 
iskola képviselójében, Maine de Biran kortársában, a szenzualista Destutt de Tracy-ban látta a klasszikus episztémé legtisztább megnyilvánulását. Horváth amellett érvel, hogy Maine de Biran filozófiájában az életfogalom hangsúlyos volta, az organikus elevenség és ennek nyomán a test tematizálása, a látás helyett a tapintás, mint kitüntetett érzék azok a határozott momentumok, melyek a modern episztémének is jellemzői. Ha Maine de Biran nem is a legjelentősebb szerzők egyike, ez a filozófiai paradigmaváltás mégis indokolja a „filozófiai portörlést”. 